\section{PROPERTIES OF CONCRETE CONTAINING BLENDED CEMENT AND LIGHTWEIGHT ARTIFICIAL AGGREGATE}

\author{
Chandra Junedy Tanaka ${ }^{a *}$ Abdul Rahman Mohd. Sam ${ }^{b}$, Norhasanah \\ Abdul Shukor Lim ${ }^{b}$, Abdullah Zawawi Awanga, Norhaliza Hamzaha, Peter \\ Loo $^{\mathrm{C}}$
}

aSchool of Civil Engineering, Faculty of Engineering, Universiti Teknologi Malaysia, 81310 UTM Johor Bahru

bUTM Construction Research Centre (UTMCRC), Institute for Smart, Infrastructure and Innovative Construction, School of Civil Engineering, Faculty of Engineering, Universiti Teknologi Malaysia, 81310 UTM Johor Bahru, Johor

'Active Pozzolan Technology Sdn Bhd, PLO 99, Jalan Nibong 2, Kompleks Perindustrian Tanjung Langsat, 81700, Pasir Gudang, Johor
Article history

Received

09 December 2019

Received in revised form

26 March 2020

Accepted

29 March 2020

Published online

31 July 2020

*Corresponding author
tanaka@graduate.utm.my

\begin{abstract}
The limitation of natural resources and the increase in industrial waste materials have been being the main concern in many developing countries. Therefore, many studies have been conducted to investigate the feasibility of industrial by-products to be used as artificial aggregate in concrete manufacturing. This study examined the influences of using artificial materials as aggregate replacement of natural aggregate and active pozzolana cement as a binder in concrete. Numbers of tests were performed to investigate the fresh and hardened concrete properties in terms of workability, density, expansion and shrinkage, ultrasonic pulse velocity, flexural strength, compressive strength and mode of failure. The specimens consist of cube and prism were prepared and tested after 3, 7 and 28 days of water curing and air curing. Results of concrete with artificial aggregates recorded lower workability due to the high water absorption, lower density of concrete, lower drying shrinkage due to the reduced free water content and lower pulse velocity in concrete. However, the compressive and flexural strengths were improved by $10 \%$ and $38 \%$ as of normal concrete, respectively. Therefore, the results obtained from this study indicated that the artificial aggregates and pozzolan cement used have positive effects on concrete properties.
\end{abstract}

Keywords: Lightweight Concrete, Blended Cement, Artificial Aggregate, Ceramic Waste Aggregate, Compressive Strength.

\begin{abstract}
Abstrak
Batasan sumber asli dan peningkatan bahan buangan industri telah menjadi kebimbangan utama di banyak negara sedang membangun. Oleh itu, banyak kajian telah dijalankan untuk menyiasat kesesuaian produk sampingan industri untuk digunakan sebagai agregat tiruan dalam pembuatan konkrit. Kajian ini menentukan pengaruh menggunakan bahan buatan sebagai penggantian agregat semula jadi dan bahan pozzolana aktif sebagai pengikat dalam konkrit. Beberapa ujian dilakukan untuk mengkaji sifat konkrit segar dan keras dari segi kebolehkerjaan, ketumpatan, pengembangan dan pengecutan, halaju nadi ultrasonik, kekuatan lenturan, kekuatan mampatan dan kegagalan. Spesimen terdiri daripada kubus dan prisma yang disediakan dan diuji selepas 3, 7 dan 28 hari dalam pengawetan air dan udara. Keputusan ujikaji menunjukkan konkrit dengan agregat buatan mencatat kebolehkerjaan yang lebih rendah disebabkan oleh penyerapan air yang tinggi, kepadatan rendah konkrit, pengecutan pengeringan yang lebih rendah disebabkan oleh kandungan air bebas yang kurang dan halaju denyutan ultrasonik yang lebih rendah dalam konkrit. Walau bagaimanapun, kekuatan mampatan dan lenturan masing-masing telah meningkat sebanyak $10 \%$ dan $38 \%$ daripada konkrit biasa. Oleh itu, keputusan yang diperoleh daripada kajian ini menunjukkan bahawa agregat tiruan dan simen pozzolan yang digunakan mempunyai kesan positif terhadap sifat konkrit.
\end{abstract}

Kata Kunci: Konkrit Ringan, Simen Teradun, Agregat Buatan, Agregat Sisa Seramik, Kekuatan Mampatan.

(C) 2020 Penerbit UTM Press. All rights reserved 


\subsection{INTRODUCTION}

Many countries are still depending on the usage of concrete in their constructions, due to the manufacturing cost of concrete is more economical and affordable as compared to steel. However, the availability of natural aggregate sources is getting limited. Moreover, the use of portland cement as a binder is known to affect the environment as cement production releases carbon dioxide gas, a potential cause of the greenhouse effect. By taking the construction cost, concrete characteristic and its availability into consideration, many countries, are seeking alternative sources that are more economical and affordable in concrete manufacturing. Therefore, lightweight concrete is one of an alternatives option to solve the problem, and numerous studies have been carried out to investigate the characteristics of lightweight concrete in terms of its properties, strength and durability.

Ordinary Portland Cement (OPC) is the most commonly used material as cementitious binder in concrete. However, the application of blended cement to replace OPC has become an alternative solution in lightweight concrete manufacturing in terms of cost and reducing $\mathrm{CO}_{2}$ gas emissions effects. By adding pozzolanic material to replace part of the cement will reduce the amount of cement needed without sacrificing strength (Durant, 2013). Perhaps one of the challenges in using natural pozzolans has been their uniformity, something that can be an issue as the product is usually directly obtained from the plant rather than manufactured. Moreover, the reaction is usually slower than Portland cement hydration and requires longer moist curing (Durant, 2013). According to Kondraivendhan (2015) in his study, the compressive strength improvement is less with respect to increase in fly ash content up to 90 days compared to the normal concrete possibly due to the quality of the fly ash used.

Aggregates are contributing to the highest proportion of $60 \%-75 \%$ in the concrete mix. However, both natural coarse and fine aggregates have become depleted due to rapid development. Therefore, many works investigated the feasibility of using artificial aggregate to replace natural aggregate in concrete mix to cater the problem. The most common artificial aggregates used were a sintered fly ash, namely as Lytag. Moreover, fly ash, in terms of its availability, cost, and quality control, was one of the primary pozzolanas for blended cement (Antiohos, 2007). The use of gas-fired and coal-combustion fly ash would ensure the availability of quality fly ash for future development in concrete (Jones, 2006). Experimental works on the use of fly ash as ingredient for artificial aggregate in concrete resulted in improved compressive and flexural strength at subsequent concrete age (Ravisankar, 2015). The production capability of lightweight concrete with the use of artificial aggregate enables a cleaner and economically sustainable concrete manufacturing procedures (Terzic, 2015). Study on concrete produced by replacement of river sand with ceramic waste fine aggregate comparable performance with normal concrete but it was found that ceramic fine aggregate had higher water absorption resulted in lower workability (Koech, 2017).
Studies on the use of lightweight aggregates in concrete has commonly dealt with partial replacement of natural aggregates with artificial aggregate and the use of pozzolan as partial replacement of Portland cement. This paper reported the work on the performance of lightweight concrete by using pozzolan blended cement, lightweight artificial aggregate and ceramic fine aggregate.

\subsection{METHODOLOGY}

\subsection{Materials}

The blended cement used in this study was an Active Pozzolana Binder CEM II/B-Q 42.5N. A $10 \mathrm{~mm}$ lightweight artificial aggregate as an industrial by-product produced from Tanjung Langsat Plant, Pasir Gudang, Johor, Malaysia with loose bulk density of $850 \mathrm{~kg} / \mathrm{m}^{3}$ used as coarse aggregate. Ceramic waste as an industrial by-product collected from Pasir Gudang, Johor, Malaysia with loose bulk density $1380 \mathrm{~kg} / \mathrm{m}^{3}$ used as fine aggregate replacement in accordance with sieve analysis BS 3797:1990. However, Ordinary Portland cement (OPC) complied with Type I Portland cement ASTM C150, natural coarse aggregate and natural river sand from local sources were used as control concrete mix in accordance with BS 882:1992.

\subsection{Preparation of Lightweight Artificial Aggregate}

The artificial aggregates collected from the plants have various sizes and shapes. The aggregates were soaked and dried to determine the physical properties that are water absorption and loose bulk density in accordance with BS EN 1097-6:2013 and BS EN 1097-3:1998, respectively. The grading was conducted in accordance with sieve analysis standard BS $3797: 1990$ to obtain the $10 \mathrm{~mm}$ size artificial coarse aggregate and to obtain ceramic fine aggregate passing the $4.75 \mathrm{~mm}$ sieve.

\subsection{Concrete Mix and Preparation of Test Specimens}

A concrete mix design was performed in accordance with the Department of Environment (DOE) Method. With a constant water-cement ratio of 0.54 , four types of the concrete mixes were manufactured, namely Mix-1 (M1) that consists of $100 \%$ natural coarse aggregate, $100 \%$ natural fine aggregate and $100 \%$ ordinary portland cement (OPC). Mix-2 (M2), consist of $100 \%$ natural coarse aggregate, $100 \%$ ceramic fine aggregate and $100 \%$ blended cement (CEM II/B-Q 42,5N). Mix-3 (M3), consists of $100 \%$ artificial coarse aggregate, $100 \%$ ceramic fine aggregate and $100 \%$ ordinary portland cement (OPC). Mix-4 (M4), consists of $100 \%$ artificial coarse aggregate, $100 \%$ ceramic fine aggregate and $100 \%$ blended cement (CEM II/B-Q $42,5 \mathrm{~N})$. The mix proportions of all concrete mixes are shown in Table 1. 
Table 1 Ingredients for all concrete mixes

\begin{tabular}{|c|c|c|c|c|c|c|}
\hline \multirow{2}{*}{ No } & \multirow{2}{*}{ Material } & Per $\mathrm{m}^{3}$ & M1 & M2 & M3 & M4 \\
\hline & & $(\mathrm{kg})$ & (kg) & $(\mathrm{kg})$ & $(\mathrm{kg})$ & (kg) \\
\hline 1 & Ordinary Portland Cement (OPC) & 463 & 8.80 & 8.80 & - & - \\
\hline 2 & Blended Cement (PCC) & - & - & - & 8.80 & 8.80 \\
\hline 3 & Natural Fine Aggregate & 949.5 & 18.04 & - & - & - \\
\hline 4 & Ceramic Fine Aggregate & - & & 18.04 & 18.04 & 18.04 \\
\hline 5 & Natural Coarse Aggregate & 687.5 & 13.06 & 13.06 & - & - \\
\hline 6 & Artificial Coarse Aggregate & - & - & - & 13.06 & 13.06 \\
\hline \multirow[t]{2}{*}{7} & Water & 250 & 4.75 & 4.75 & 4.75 & 4.75 \\
\hline & Water-cement ratio $(W / C)$ & 0.54 & 0.54 & 0.54 & 0.54 & 0.54 \\
\hline
\end{tabular}

A total of twelve cube specimens of $100 \times 100 \times 100 \mathrm{~mm}$ and two prism specimens of $100 \times 100 \times 500 \mathrm{~mm}$ were fabricated for every single mix design and cured in a water tank, whilst one prism specimen was left for air curing in laboratory.

\subsection{Test on Fresh and Hardened Concrete}

The workability of the fresh concrete mix was determined by the slump test method as complied with BS EN 12350-2:2009. On hardened concrete, the density was determined in accordance with BS 1881-114:1993. The expansion and drying shrinkage tests were conducted with regard to BS 812-120 by using Demec Gauge. In addition, the Ultrasonic Pulse Velocity (UPV) test was conducted according to BS 1881-203:1986 at the age of 3,7 and 28 days by using a Portable Ultrasonic Nondestructive Digital Indicating to check the quality of concrete. The compressive strength tests on $100 \times 100 \times 100 \mathrm{~mm}$ cubes were conducted in accordance with BS EN 12390-3:2009 at the ages of 3,7 and 28 days. Whilst the flexural strength tests on a
$100 \times 100 \times 500 \mathrm{~mm}$ prism was conducted in accordance with BS EN 12390-5:2009 at the age of 28 days only.

\subsection{RESULTS AND DISCUSSIONS}

\subsection{Physical Properties of Aggregate}

The material properties for both coarse and fine aggregates are illustrated in Table 2. In general, the water absorption of ceramic fine aggregate and artificial aggregate was higher compared to natural aggregates by about two times and nine times, respectively. This was most likely due to higher porosity of the aggregates in comparison with natural aggregates. As for the loose bulk density of the artificial aggregate and ceramic fine aggregate compared with the natural aggregates was lower by $43 \%$ and $15 \%$, respectively. In addition, the ceramic fine aggregate satisfied with the grading limit, whilst the artificial aggregate grading limit satisfy to the requirement of BS 3797:1990.

Table 2 Properties of natural and artificial coarse aggregate

\begin{tabular}{|l|c|c|c|c|}
\hline & \multicolumn{2}{|c|}{ Fine Aggregate } & \multicolumn{2}{c|}{ Coarse Aggregate } \\
\hline Physical Properties & Natural Sand & Ceramic Fine Agg. & Natural Agg. & Artificial Agg. \\
\hline Water Absorption (\%) & 2.3 & 4.5 & 1.43 & 13.25 \\
\hline Loose bulk density $\left(\mathrm{kg} / \mathrm{m}^{3}\right)$ & 1618 & 1380 & 1490 & 850 \\
\hline
\end{tabular}

\subsection{Properties of Fresh Concrete}

A slump test was conducted to measure the level of workability of all concrete mixes. The results presented in Figure 1 show that the workability of fresh concrete mix M2, M3 and M4 was lower as compared to control concrete, M1. The reduction of workability was in the range of 20 to $30 \%$. This might be due to the presence of more voids in artificial aggregate and ceramic fine aggregate as indicated in Table 2 . The test result shows that, ceramic and artificial aggregate with high water absorption requires additional water during the mixing process to create fresh concrete with good workability (Tang, 2017). Additional water can be used and calculated based on the level of absorption of the aggregates to ensure it will not change the design water-cement ratio. 


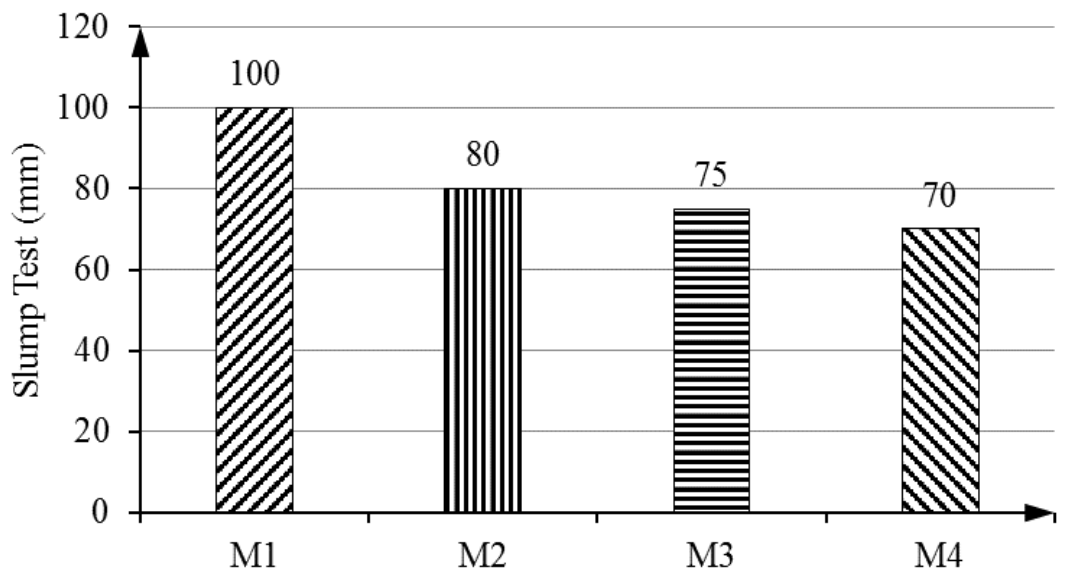

Figure 1: Slump test result

Figure 2 illustrates the hardened concrete density of all concrete mixes. It shows that the average density of control mix M1 was higher in the range of 7 to $13 \%$ as compared to concrete mixes M2, M3 and M4 at all curing ages. However, at 28 days curing age, both mixes M3 and M4 recorded the lowest density among others, these were due to the highest content of artificial aggregates with lower bulk density.

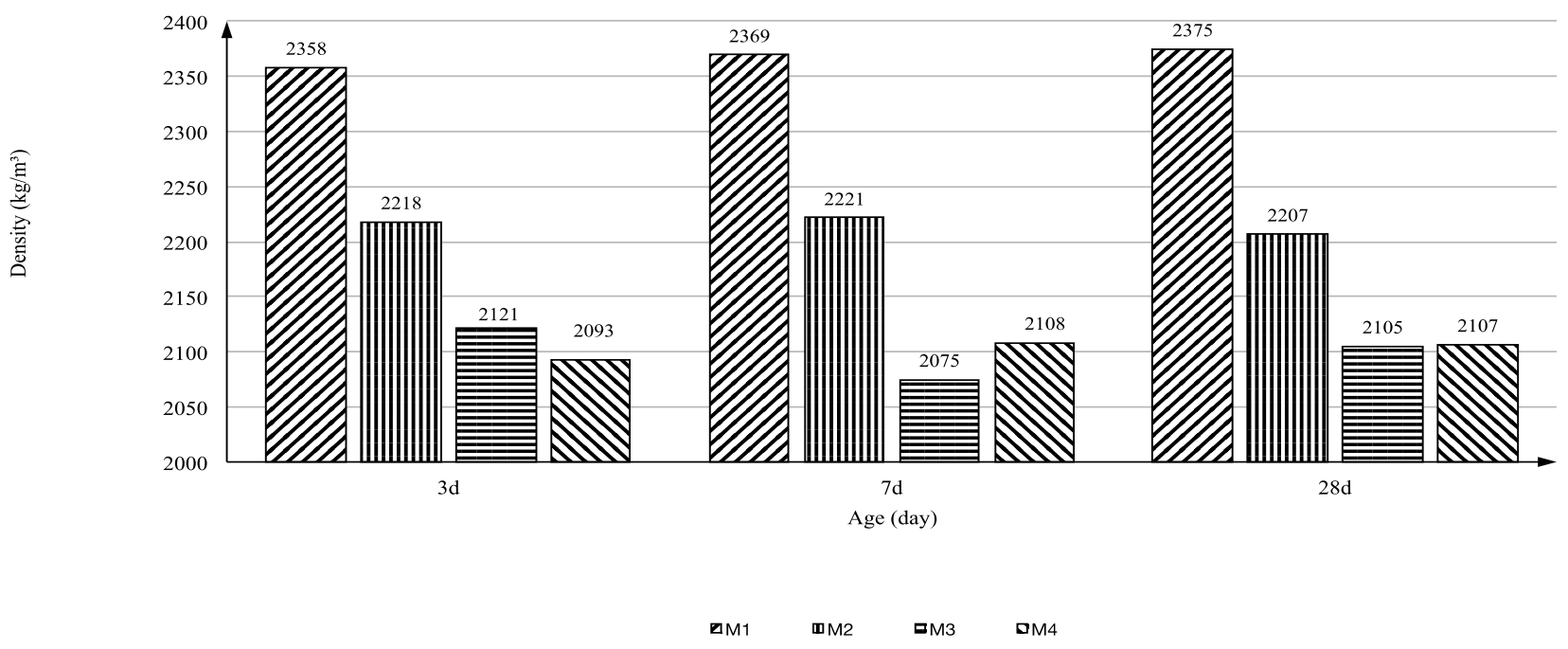

Figure 2 Hardened density of concrete M1, M2, M3 and M4

\subsection{Ultrasonic Pulse Velocity}

Figure 3 illustrates that the pulse velocity of concrete mixes M2, M3 and M4 were lower than that of control concrete mix, $M 1$, in all curing ages. The recorded values were in the range of 3.5 to $4.4 \mathrm{~km} / \mathrm{s}$ at the age of 28 days. This was probably due to the presence of large air voids in the artificial aggregate in the concrete mix that reduce the velocity of the pulse. Higher pulse velocity readings indicate good quality of concrete with less pores or voids. Lower voids in concrete will also contribute to better strength and durability of the hardened concrete. 


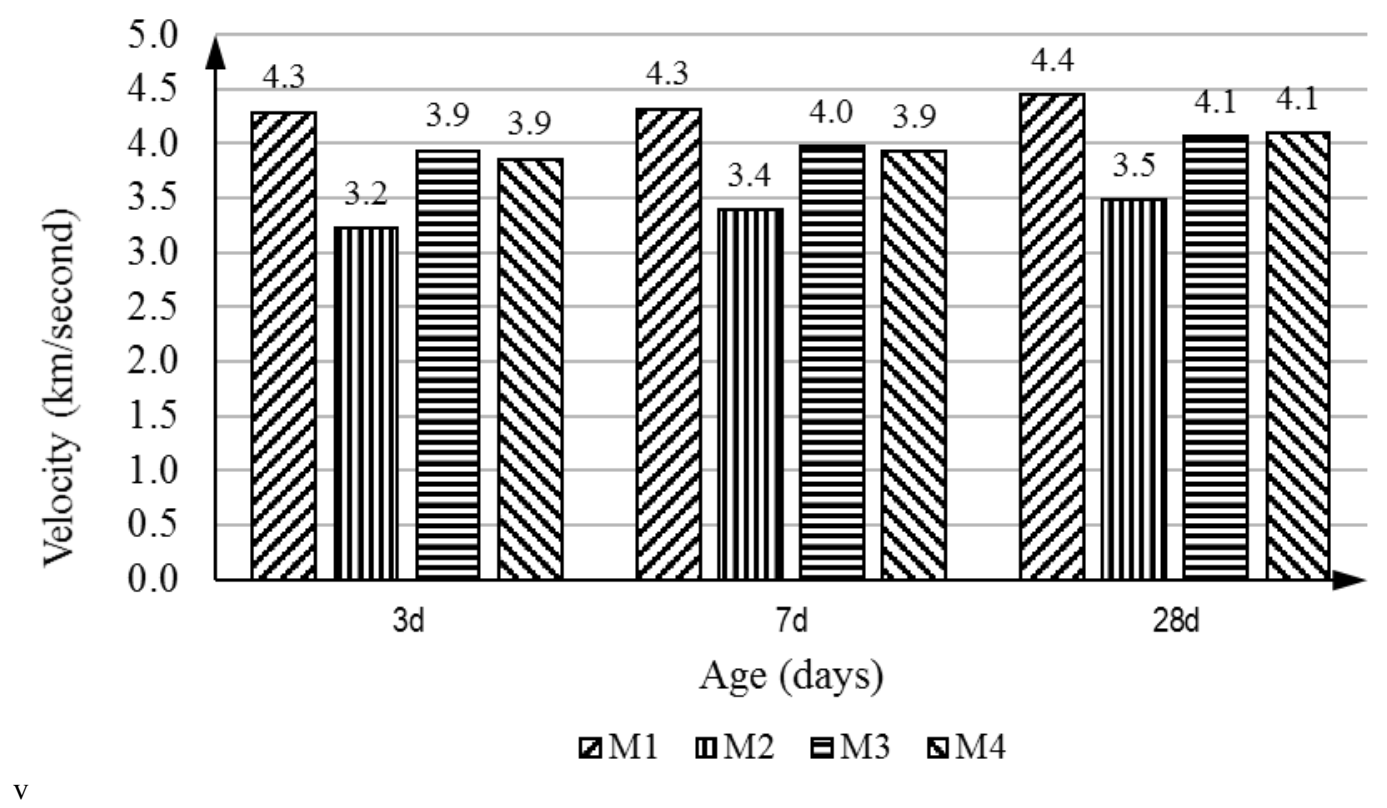

Figure 3: Ultrasonic Pulse Velocity of Concrete Mix M1, M2, M3 and M4

Figure 4 shows the relationship between compressive strength and ultrasonic pulse velocity of concrete mixes $M 1, M 2, M 3$ and M4 at different curing ages. It can be seen that the trend shows that both UPV and compressive strengths were low at early stages but increased with the increase of curing age. This might be due to the slow generation of $\mathrm{C}-\mathrm{S}-\mathrm{H}$ gel and pozzolanic reaction during the hydration process (Hasan, 2000).
As the generation of $\mathrm{C}-\mathrm{S}-\mathrm{H}$ gel increased the value of the pulse velocity also increased due to denser microstructure of the concrete. It can be seen from te figure that result of the R2 is in the range of 0.85 to 0.95 indicating a good correlation of the test results.

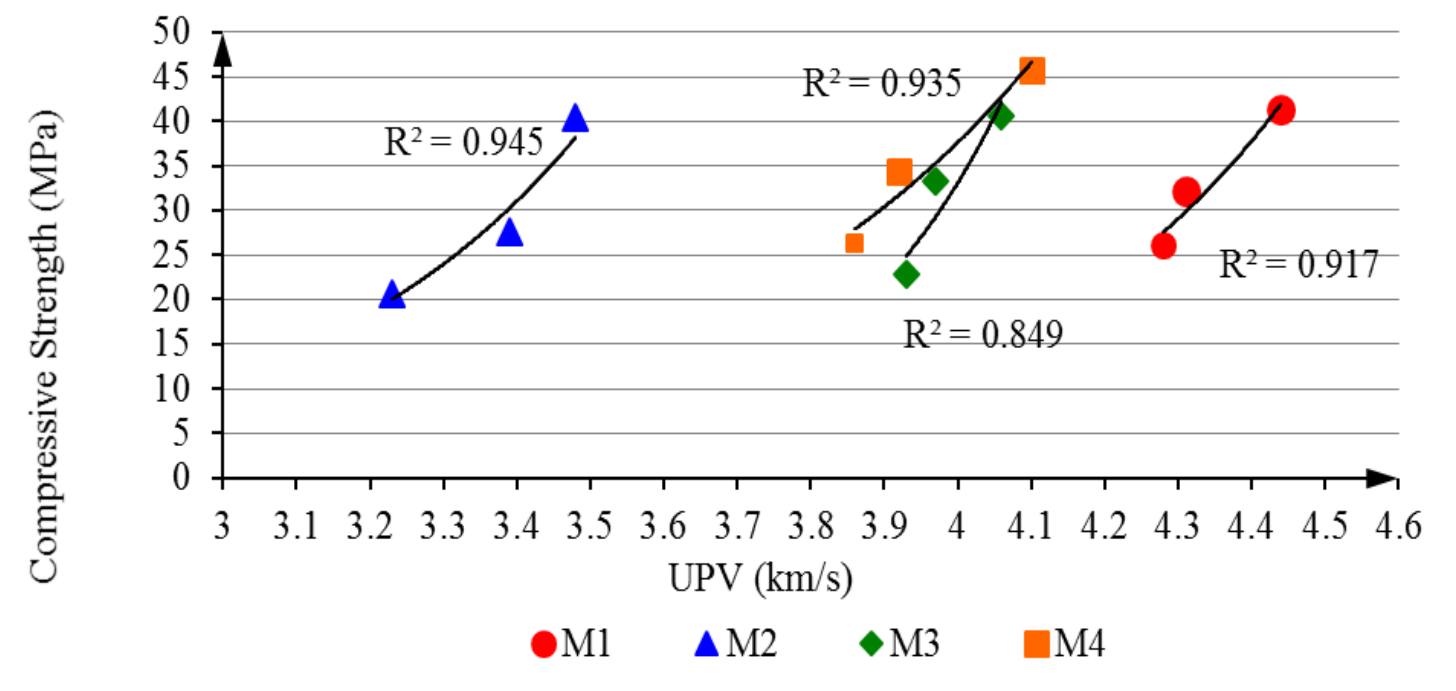

Figure 4 Correlation between Compressive Strength and Ultrasonic Pulse Velocity of Concrete Mixes M1, M2, M3 and M4

\subsection{Expansion and Drying Shrinkage}

Figure 5 shows the relationship between expansion-shrinkage with time. It can be seen that the expansion and shrinkage of all specimens were higher at early age and started to be constant after the age of 7 days. Concrete mix M4 shows the lowest expansion and shrinkage values compared with other mixes. This indicates the positive effect of ceramic fine aggregate and artificial aggregate when used in concrete mix. It may be due to the low free water content in concretes. When 
the specimens exposed to environmental humidity (Relative Humidity, RH less than $100 \%$ ), the specimens begin to lose the free water, the volume decreased and continued to dry and shrink. At an early age, the size and concentration of calcium hydroxide and ettringite were less, therefore, causing higher shrinkage, whereas at a mature age the shrinkage decreased as capillary voids in concrete reduced by the generation of more $\mathrm{C}-\mathrm{S}-\mathrm{H}$ gel. The recorded values of expansion and shrinkage for all concrete mixes were in the range of 110 to 160 and 80 to 115 microstrains, respectively.

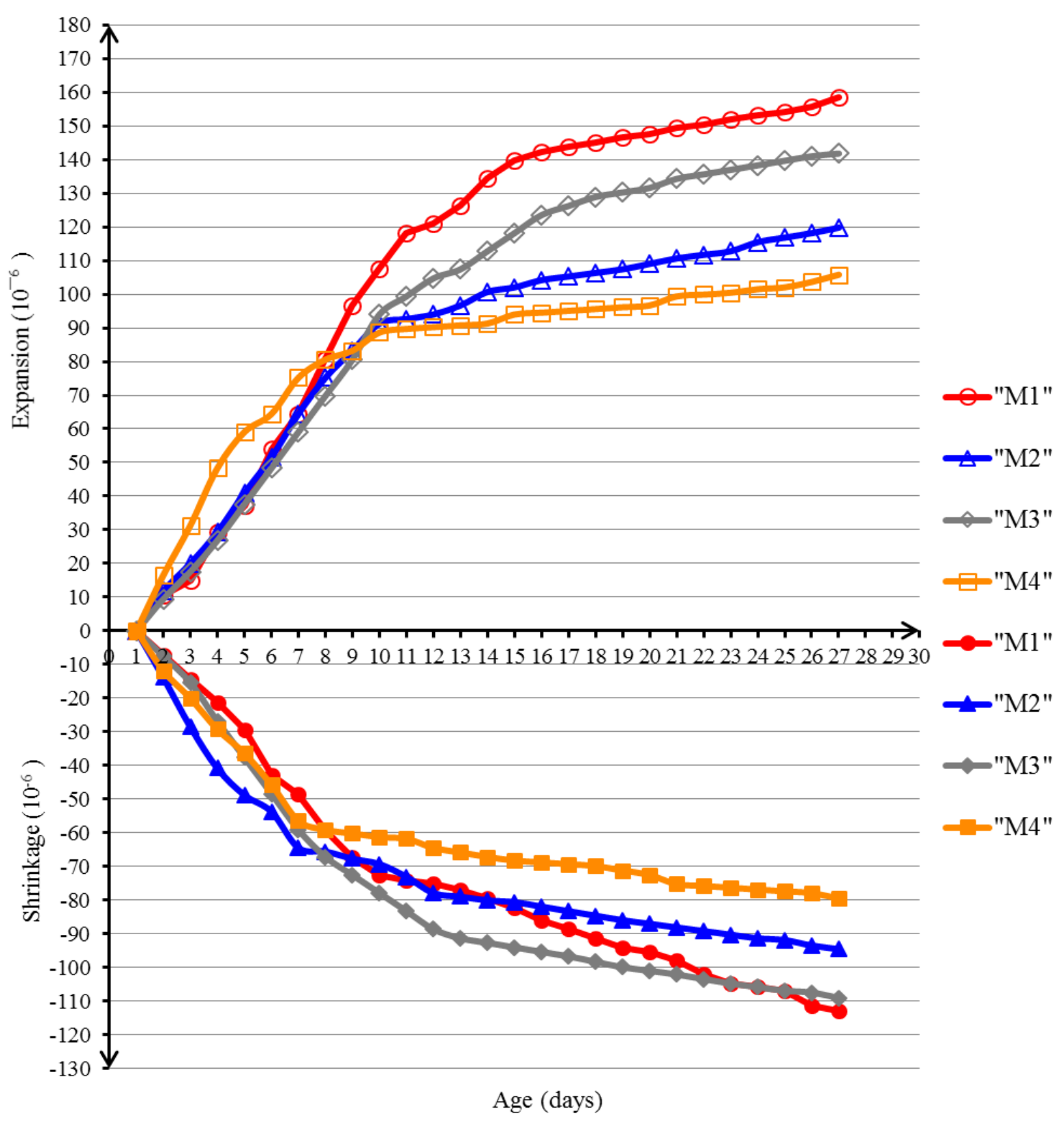

Figure 5 Expansion and Drying Shrinkage Concrete Mix M1, M2, M3 and M4 


\subsection{Compressive Strength}

The compressive strength values of the concrete specimen are presented in Figure 6 . In this study, the targeted compressive strength was designed for $30 \mathrm{MPa}$ at 28 days. Results show that the compressive strength of mix M4 at 28 days was the highest that is $45.70 \mathrm{MPa}$ followed by $\mathrm{M} 1$ (41.39 MPa), M3 (40.56 MPa) and $\mathrm{M} 2(40.45 \mathrm{MPa})$ which exceeded the target strength by $52 \%, 38 \%, 35 \%$, and $35 \%$, respectively. This may be due to concrete M4 contained the highest percentage of pozzolana blended cement, artificial aggregate and ceramic fine aggregate, therefore the secondary reaction of blended cement produced extra $\mathrm{C}-\mathrm{S}-\mathrm{H}$ gel that might reduce the capillary void and the crystal $\mathrm{Ca}(\mathrm{OH}) 2$ will be replaced by the extra C-S-H gel that contributed to increasing the concrete strength.
Furthermore, the adhesion between artificial aggregates and blended cement paste were likely to increase as the $\mathrm{Ca}(\mathrm{OH}) 2$ crystals reduced, therefore contributed to increasing the concrete compressive strength.

However, the strength development of concretes $M 2$, M3 and M4 were slower at the beginning curing age compared with control mix M1, this was due to blended cement concrete has relatively lower C-S-H gel at early ages (Hasan, 2000). However, its pozzolanic reactivity would improve its resistance in aggressive media at later ages (Naik, 1998). This illustrated that the pozzolanic reaction of blended cement was a longterm process with the contribution to the growth in compressive strength of concrete even after 28 days of curing time.

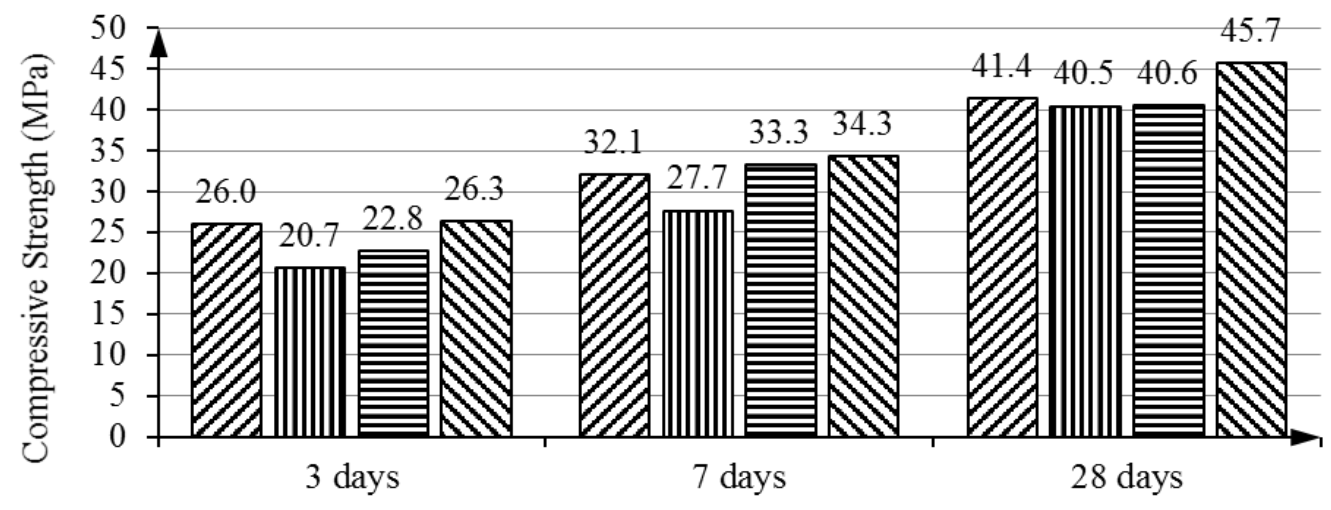

Concrete Age (Days)

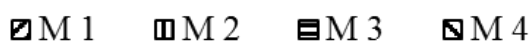

Figure 6 Compressive Strength of Concrete Mix M1, M2, M3, and M4

\subsection{Flexural Strength}

Figure 7 illustrates the average flexural strength of concrete mixes $\mathrm{M} 2$, $\mathrm{M} 3$, and M4 at 28 days were higher than the control mix M1. However, mix M4 recorded higher results compared with mix M2 and M3 by $16 \%$ to $27 \%$, respectively. This possibly due to the presence of a high percentage of both pozzolana blended cement and artificial aggregate in mix $\mathrm{M} 4$ in which at 28 days, the $\mathrm{Ca}(\mathrm{OH}) 2$ crystals reduced and formed extra C-S-H gel. Moreover, the volume and size of voids in the Interfacial Transition Zone reduced by the increase of the crystallization of hydrated products and formation of $\mathrm{C}-\mathrm{S}-\mathrm{H}$, therefore the flexural strength increased.

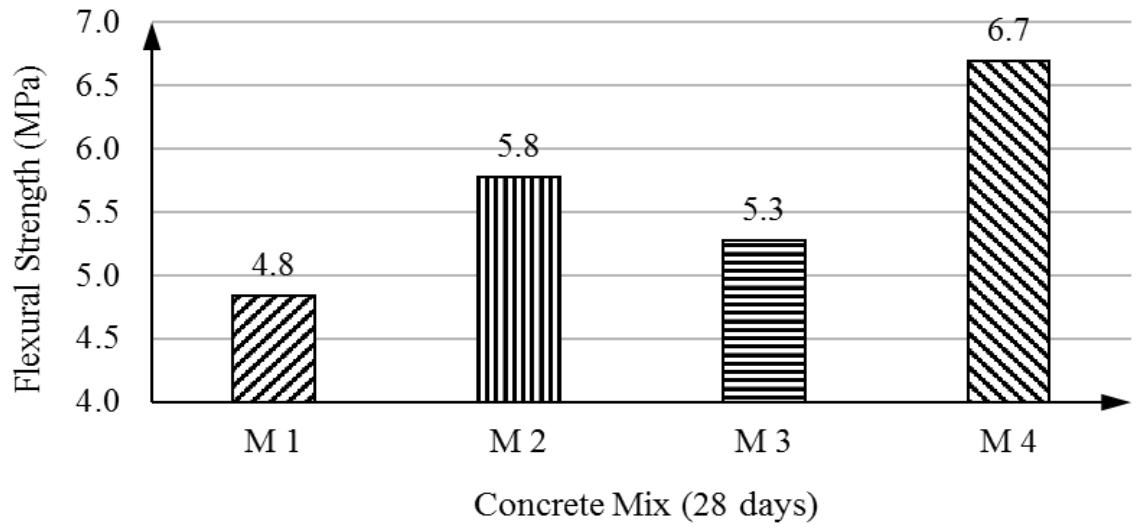

Figure 7 Flexural Strength of Concrete Mix M1, M2, M3, M4 
Figure 8 shows the relationship between compressive strength and flexural strength of specimens tested. It can be seen that the calculated ratio between flexural strength to compressive strength at 28 days was in the range of 0.11 to 0.15 . This value indicates that the modulus of rupture based on the flexural strength test for concrete is about 10 to $15 \%$ of the concrete compressive strength. The correlation is given by the $R^{2}$ value of 0.995 that nearly to unity.

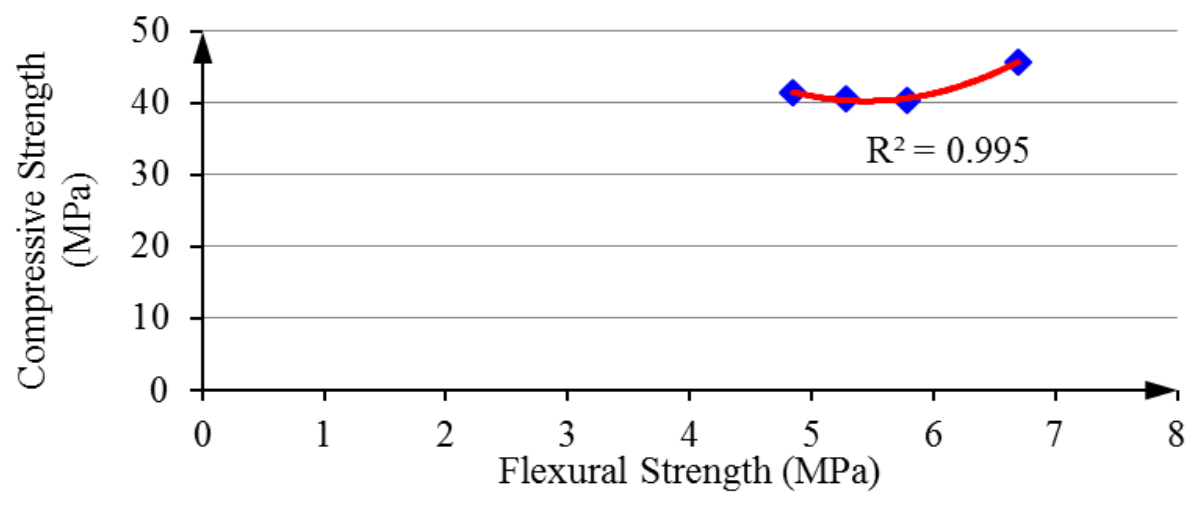

Figure 8 Correlation between compressive and flexural strengths

\subsection{Mode of Failure}

The failure mode of concretes $\mathrm{M} 2, \mathrm{M} 2$ and $\mathrm{M} 3$ under the axial compression were basically similar to the control concrete M1 as shown in Figure 9.

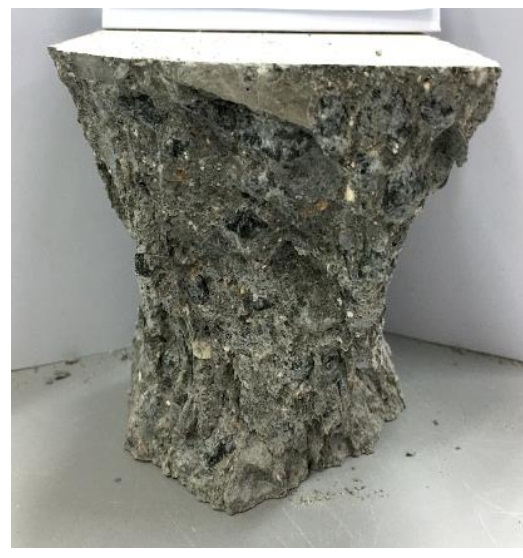

M1

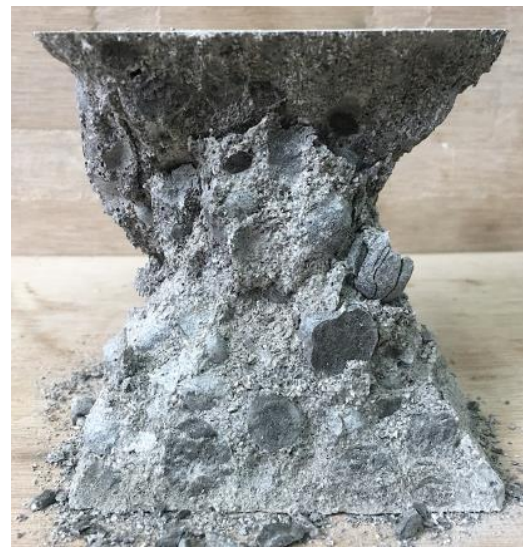

M3

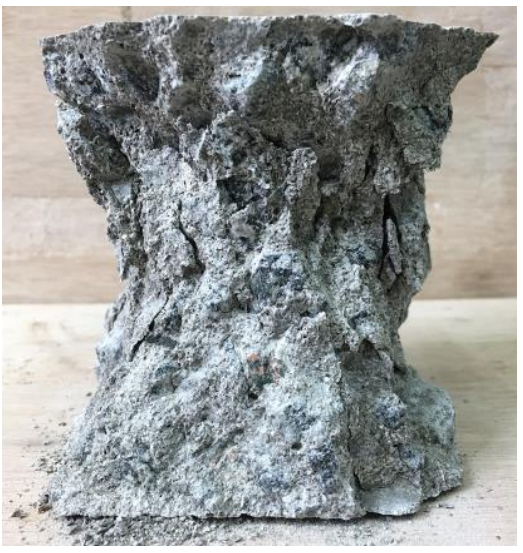

M2

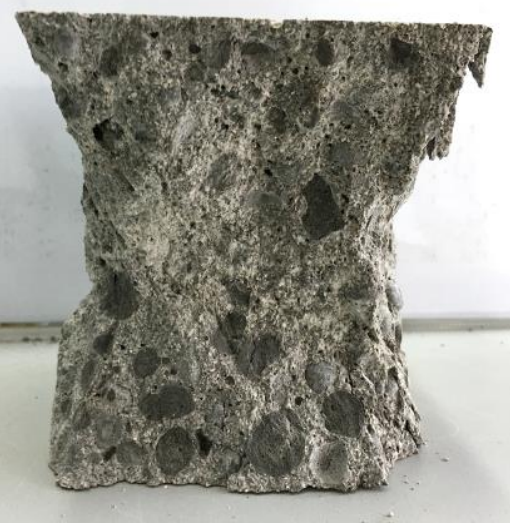

M4

Figure 9 Mode of Failure of Specimens 
Figure 10 shows the general possible failure sections of all concrete specimens consist of three parts: (1) failure in between bonding, (2) failure on bonding, (3) failure on aggregate. In general, failures in between bonding were more often seen. However, in artificial aggregate concrete mix M3 and $\mathrm{M} 4$, it was observed that the failure on aggregate was

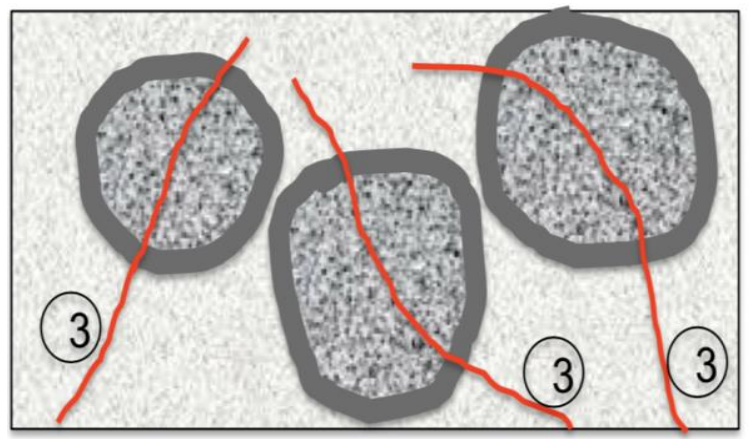

more often to occur. This might be due to the artificial aggregate has lower specific gravity and lower density as compared with natural gravel. However, in normal aggregate concrete the fracture mostly happened in between bonding and on bonding because the aggregates were denser and stronger, as illustrated in Figure 11.

Figure 10 Failure Section Pattern (a) Artificial Aggregate Concrete (b) Normal Weight Aggregate Concrete

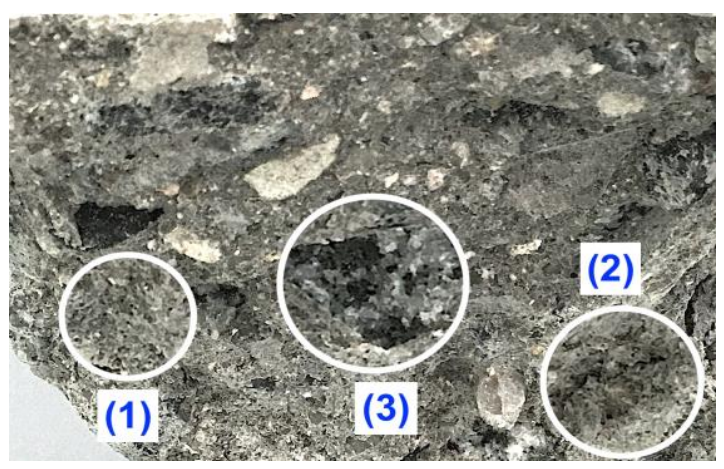

M1

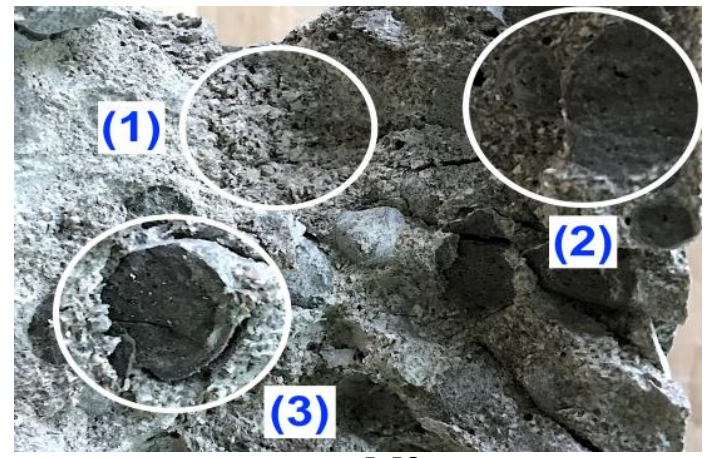

M3

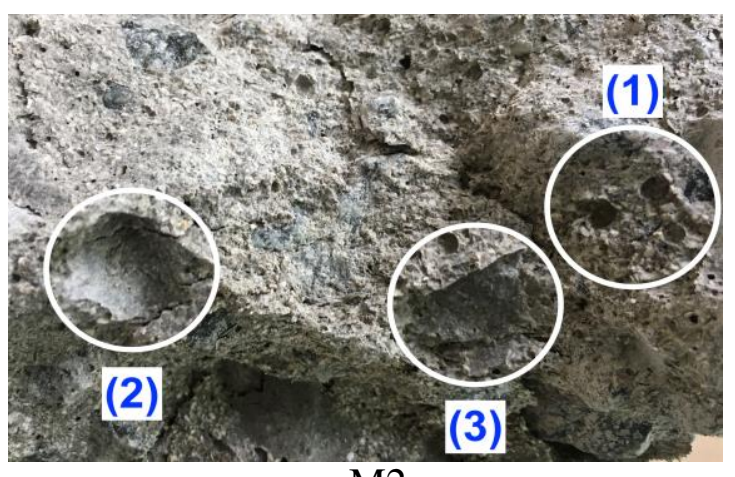

M2

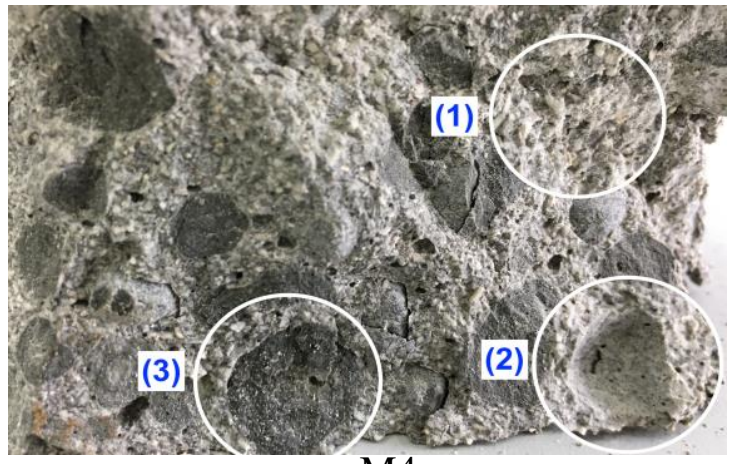

M4

Figure 11 Crack Pattern of Specimens 


\subsection{CONCLUSIONS}

Based on the laboratory results obtained, the conclusions that can be drawn are as follows:

1. The artificial aggregate concrete $M 3$ and $M 4$ incorporated with blended cement, artificial aggregate and ceramic waste fine aggregate have recorded an average density of $2100 \mathrm{~kg} / \mathrm{m}^{3}$ which is less than the normal concrete $\mathrm{M} 1$ of $2300 \mathrm{~kg} / \mathrm{m}^{3}$, although still higher than the expected density of $1800 \mathrm{~kg} / \mathrm{m}^{3}$. However, this will contribute to reducing the greenhouse effect in the environmental, by utilizing the industrial by-product to produce commercial concrete.

2. Incorporating $100 \%$ blended cement, $100 \%$ artificial aggregate and $100 \%$ ceramic fine aggregate into concrete mix has increased the compressive strength and flexural strength by $10 \%$ and $38 \%$, respectively, as compared with control concrete. Moreover, the workability of fresh concretes with artificial and ceramic aggregates was lower as compared to normal weight concrete. Furthermore, the pulse velocity recorded was also lower compared with control concrete due to the properties of aggregates used. In addition, the expansion and drying shrinkage of the tested concretes were lower compared with control indicating improvement on concrete properties.

3. Under the axial compression, the lightweight artificial aggregate concretes failures shown as a satisfactory failure, means that it has similar behavior as of control concrete. The failure of the all concrete specimens can be attributed to brittle failure with obvious crack, consists of three parts that are either failure in between bonding, failure on bonding and failure on aggregate. However, the fracture in lightweight artificial aggregate concrete mostly happens on aggregate due to its lower density and strength compared to natural aggregate.

4. The experimental results show that the artificial aggregates and ceramic waste fine aggregate can be used as aggregates replacement in concrete with comparable performance as normal concrete. This indicates that green and sustainability concept in construction can be achieved through, to some extent, the use of waste materials as aggregate in construction industry.

\section{Acknowledgements}

The authors would like to acknowledge the research grants provided by Universiti Teknologi Malaysia and International Research Grant, Q.J130000.3009.01M95 and R.J130000.7309.4B469 in this research work. The authors also would like to thank Active Pozzolan Technology Sdn. Bhd. for providing the materials used in this study.

\section{References}

[1] Antiohos, S.K., Papadakis, V.G., Chaniotakis, E., and Tsimas, S. 2007 Improving the Performance of Ternary Blended Cements by Mixing Different Types of Fly Ashes. Cement and Concrete Research. 37(6):877-885

[2] British Standards Institution. 1990. Specification for Lightweight Aggregate for Masonry Units and Structural Concrete. London, BS 3797.

[3] British Standards Institution. 2013. Tests for mechanical and physical properties of aggregates Part 6: Determination of particle density and water absorption. London, BS EN 1097-6.

[4] British Standards Institution. 1998. Tests for Mechanical and Physical properties of Aggregates-Part 3: Determination of Loose Bulk Density and Voids. London, BS EN 1097-3.

[5] British Standards Institution. 2009. Testing hardened concrete-Part 3 : Compressive strength of test specimens. London, BS EN 12390-3.

[6] British Standards Institution. 2009. Testing Hardened Concrete-Part 5: Flexural Strength Of Test Specimens. London, BS EN 12390-5.

[7] British Standards Institution. 1983. Method for Determination of Slump-Part 102. London, BS 1881-102.

[8] British Standards Institution. 2009. Testing fresh Concrete-Part 2: Slump Test. London, BS EN 12350-2.

[9] British Standards Institution. 1983. Testing concrete-Part 114: Methods for Determination of Density of Hardened Concrete. London, BS 1881-114.

[10] British Standards Institution. 1989. Testing Aggregates-Part 120: Method For Testing And Classifying Drying Shrinkage Of Aggregates In Concrete. London, BS 812-120.

[11] British Standards Institution. 1986. Testing Concrete-Part 203: Recommendations for Measurement of Velocity of Ultrasonic Pulses in Concrete. London, BS 1881-203.

[12] British Standards Institution. 2009. Testing Hardened Concrete-Part 2: Making And Curing Specimens For Strength Tests. London, BS EN 12390-2.

[13] British Standards Institution. 2002. Testing hardened concrete-Part 3: Compressive Strength Of Test Specimens. London, BS EN 12390-3.

[14] British Standards Institution. 1992. Specifications for Aggregate From Natural Sources for concrete. London, BS 882.

[15] British Standards Institution. 1990. Specification for Lightweight Aggregate for Masonry Units and Structural Concrete. London, BS 3797.

[16] Durant, A., Bigley, C.H and Milestone, N.B. Pozzolans and Admixtures - How can we use these to our best advantage?. NZ Concrete Industry Conference. 3-5 October 2013. Millennium Hotel Queenstown, New Zealand.

[17] Hassan, K.E., Cabreba, J.G and Maliehe, R.S. 2000. The Effect of Mineral Admixtured on the Properties of High-performance Concrete. Cement and Concrete Composite. 22(4): 267-271.

[18] Jones, M.R., Sear, L.K.A., McCarthy, M.J., and Dhir, R.K. 2006 Changes in Coal Fired Power Station Fly Ash: Recent Experiences and Use in Concrete. Ash Technology Conference. Birmingham: UK Quality Ash Association.

[19] Kondraivendhan, B. and Bhattacharjee, B. 2015. Flow Behaviour and Strength for Fly Ash Blended Cement Paste and Mortar. International Journal of Sustainable Built Environment. 4(2):270-277.

[20] Naik, T.R., Singh, S.S and Ramme, B.W. 1998. Mechanical Properties and Durability of Concrete Made with Blended Fly Ash. ACl Material Journal. 95(4): 454-462.

[21] Ravisankar, K.L and Gowtham, S.K. 2015. Experimental Study on Artificial Fly Ash Aggregate Concrete. International Journal of Innovative Research in Science, Engineering and Technonoly. November, 4(11): 11124-11132

[22] Terzic, A., Pezo, L., Mitic, V. and Radojevic, Z. 2015. Artificial Fly Ash Based Aggregates Properties Influence on Lightweight Concrete Performances. Ceramic International. 41(2) Part B: 2714-2726.

[23] Tang, P., Florea, M.V.A and Brouwers, H.J.H. 2017. Employing Cold Bonded Pelletization to Produce Lightweight Aggregates from Incineration Fine Bottom Ash. Journal of Cleaner Production. 165(14): 1371-1384. 